\title{
Left Subclavian Artery
}

National Cancer Institute

\section{Source}

National Cancer Institute. Left Subclavian Artery. NCI Thesaurus. Code C32972.

An artery arising from the aortic arch that supplies the left arm. 